\title{
Overreliance on bronchodilators as a risk factor for life-threatening asthma
}

\author{
Pierre ERnst mD, Brenda Hemmelgarn mn, Donald W CockCroft mD, SAmy Suissa PhD \\ Department of Epidemiology and Biostatistics and Department of Medicine, \\ Montreal General Hospital, McGill University, Montreal; and Department of Medicine, \\ University of Saskatchewan, Saskatoon, Saskatchewan
}

P ERnSt, B Hemmelgarn, DW Cockcroft, S Suissa. Overreliance on bronchodilators as a risk factor for life-threatening asthma. Can Respir J 1995;2(1):34-39.

OBJective: To assess the potential impact on the risk of life-threatening asthma of current recommendations in pharmacotherapy, which emphasize the early use of steroids and the avoidance of beta-agonist overuse.

DESIGN: Nested case-control study.

SeTting: Province of Saskatchewan.

Population Studied: From al cohort of 12,301 subjects dispensed 10 or more asthma medicattions from 1980 to 1987. 129 case patients were identified who hat experienced an episode of fatal or near fatal asthma and 129 control patients matched to the cases on age, time period at risk and severity of asthma (as judged by the need for hospitalization for asthma in the preceding two years).

METHODS: Two clinicians reviewed the therapy these 258 subjects had been dispensed over the prior two-year period and classified their treatment as 'incompatible' or 'compatible" (at least partially compatible) with current pharmaco- therapeutic guidelines. In addition to this classification a treatment evaluation score was also applied to each study subject. This score was based on the use of anti-inflammatory therapy (oral and inhaled) in conjunction with the regular use of bronchodilators, as well as the use of oral corticosteroids for patients recently discharged from hospital following an attack of asthma.

Results: At least one of the two clinician reviewers judged therapy to be incompatible with current standards in $49 \%$ of the case patients compared with $20 \%$ of the subjects who had not experienced a life-threatening episode. The mean $\pm \mathrm{SD}$ treatment score was $3.5 \pm 1.7$ in cases compared with $0.8 \pm 1.4$ in controls, suggesting quality of pharmacological treatment was worse in cases $(\mathrm{P}<0.001)$. Conclusions: Pharmacological therapy incompatible with current recommendations was more common among cases of fatal and near fatal asthma in Saskatchewan from 1980 to 1987 . (Pour résumé, voir page 35)

Key Words: Adverse effects, Betu-asomists. Conteosternids, l) rug therapy, Morbidity, Mortality

Correspondence: Dr Pierre linnst, Respiratory Epidemiology Unit, Department of Epidemiology and Biostatistics, Ma (iill Universits. 1110 Pinc Avenue West, Montreal, Quehec 113.4 143. T'lephone (514) 398-6974, Fax (514) 398-8981 


\section{La confiance excessive dans les bronchodilat- ateurs comme facteur de risque pour un épisode d'asthme mettant la vie du patient en danger}

OBJECTIF : Évaluer l'impact potentiel des recommandittions en vigueur en matière de pharmacothérapie. qui rappellent d'utiliser précocement des stérö̈des et d'éviter lit surutilisation des bêta-agonistes, sur le risque d'un épisode d'asthme mettant la vie du patient en danger.

ModÈLE : Étude cas/témoins emboîtés

CONTEXTE : Province de la Saskatchewan.

Population ÉTudiée: D’une cohorte de 12.301 sujets it qui on a prescrit 10 médicaments anti-asthmatiques et plus, de 1980 à 1987. 129 patients-cas ont été identifiés qui avaient subi un episode disthme tatal ou presque fialal. et 129 patients-témoins étaient appariés aux cas pour l'âge, la durée du risque et la gravité de l'asthme (jugé par le besoin d'hospitalisation causée par l'asthme dans les deux années précédentes).

Méthodes : Deux cliniciens ont palssé en revue lé traliement qui avait été prescrit à ees 258 sujets pendint les deux années précédentes et l'ont classifić comme «incompatible» ou «compatible» (du moins partiellement compatible) alvec les lignes directrices en vigueur de la pharmacothérapie. En plus de celte classification, une cote d'évaluation clu traitement a également été appliquée à chaque suj̣ct participant à l'étude. Cette cote était basée sur l"utilisation d'agents antiinflammatoires (par voie orale ou par inhalation) en conjonction avec l'utilisation régulière de bronchodilatateurs. de même que sur l'utilisation de corticostérö̈des pour les patients qui venaient de quitter l"hôpital après avoir souffert (1'une crise d'asthme

RÉSUltats : Au moins un des deux réviseurs cliniciens a juge le traitement incompatible avec les normes en vigueur chey 49\% des patients-cas comparativement it $20 \%$ des sujets qui n'avaient pas subi un épisode mettant leur vie en danger. La moyenne \pm écart-type de la cote du traitement était de $3,5 \pm 1,7$ pour les cas comparativement à $0,8 \pm 1,4$ pour les témoins, indiquant que la qualité du traitement pharmacologique était plus mauvaise chez les cas $(\mathrm{P}<0,001)$.

CONClusions : Un traitement pharmacologique incompatible avec les recommandations en vigueur était plus courant chez les cas d'asthme fatal et presque fatal en Saskatchewan, de 1980 à 1987.
$\mathrm{A}$ STHMA MORI3IIITY AND MORTALITY HAVE BEEN INcreasing in a number of countries despite recent scienlific advances that have improved the understanding of this chronic lung condition (1-3). The treatment ol asthma has been identified as a potential contributing factor to this increasing morbidity and mortality (4-6). In the past, pharmacological treatment of asthma locused on bronchodilator therapy, but the more recent recognition that chronic asthmal involves a characteristic inflammilory response in the airwalys hats changed the therapeutic management of asthmat (7-9). This greater emphasis on anti-inflammatory therapy and decreased reliance on bronchodilators atome is rellected in the revised guidelines for the treatment of asthma disseminated to the medical community in written reports as well as scientific journals (1)-1.3).

The primary objective of the present study was to estimate the potential impact that this change in emphasis might have by comparing pharmacotherapy in asthmatics with or without it life-threatening episode in Saskatchewan from 198010 1987. This was accomplished in two ways: first, by having two clinicians review clinical and drug treatment information on all cases of life-threatening asthma and a similar number of control patients with asthma who had not had a life-threatening episode, and subsequently classify their phamalcolherapy as 'incompatible' or 'partially compatible' with curcent pharmacolherapeutic recommendations, as first formalied in the Canadian Asthma Guidelines (12); and second, by applying an 'Asthma Management Score' to each of the calses and selected controls to obtain a numerical index of the degree of "ineompatibility". A further objective of this study was to determine whether fenoterol was more likely than albuterol to have heen prescribed in subjects who overrely on bronchodilators.

\section{PATIENTS AND METHODS}

Overall study design: As previously reported (14). a nested case-control design was used 10 examine the relationship between the use of beta-agonists and the risk of death and near death from asthma. Briefly, linked health insurance databases of the province of Salskatchewan were used to identify a cohort of $12.30 \mathrm{~J}$ patients who were dispensed 10 or more prescriptions for an asthma medication between damtary 1, 1978 and April 30. 1987. These medications were not available without a prescription and a dispensing record wats required for the pharmacist to be directly reimbursed by the government, which pays for all prescribed medications. Subjects had to be belween the alges of live and 54 years during the study period (January 1. 1980 to April 30. 1987) to be considered at rish. Predetermined criteriat were used to identily case pationts who died of asthnal during the study period (44 patients) of for those who survived, experienced a near-fatal asthmatic episode (85 patients). A noar-fatal event was defined as intubation, mechanical ventilation, or $\mathrm{PCO}_{2}$ greater than $45 \mathrm{mmHg}$ during a hospitalization for asthma. Up to eight controls were selected from anmong the cohort of $12,3(0) 1$ and were matched to each catse palient on the basis of age at entry into the colort. date of entry, the occurrence of a hospitalisation for atsthma in the prior two years, region of residence and receipt ol social assistance at any time during the study. In addition, the controls were requited to have been at risk for the outcome at the time of the event in the case patient. referred to als the index 
TABLE 1

\section{Asthma management score}

\begin{tabular}{|c|c|}
\hline Criteria & Points \\
\hline \multicolumn{2}{|c|}{$\begin{array}{l}\text { Average number of beta-agonist inhalers per month } \\
\text { (prior } 12 \text { months) }\end{array}$} \\
\hline$>3$ & 3 \\
\hline$>2 \leq 3$ & 2 \\
\hline$\geq 1.5 \leq 2$ & 1 \\
\hline$<1.5$ & 0 \\
\hline \multicolumn{2}{|c|}{$\begin{array}{l}\text { Anti-inflammatory therapy (number of prescriptions dispensed } \\
\text { during prior } 12 \text { months) }\end{array}$} \\
\hline none & 3 \\
\hline$<3$ & 2 \\
\hline $23 \leq 11$ & 1 \\
\hline$>11$ & 0 \\
\hline \multicolumn{2}{|l|}{ Use of contraindicated drugs ${ }^{\dagger}$} \\
\hline $\begin{array}{l}\text { within } 1 \text { month of index event or } \\
\text { hospitalization for asthma }\end{array}$ & 2 \\
\hline $\begin{array}{l}2 \text { to } 12 \text { months before index event or } \\
\text { hospitalization for asthma }\end{array}$ & 1 \\
\hline \multicolumn{2}{|c|}{$\begin{array}{l}\text { Most recent acute attack requiring hospitalization within } \\
12 \text { months before index event not adequately treated }\end{array}$} \\
\hline no corticosteroids & 2 \\
\hline inhaled corticosteroids only & 1 \\
\hline Maximum score & 10 \\
\hline
\end{tabular}

*includes oral corticosteroids, inhaled corticosteroids, and inhaled cromolyn: ${ }^{\dagger}$ Includes beta-blockers, sedatives and parasympathomimetics

date. A tonal of 655 controls were matched to the 129 case patients.

Clinical information was obtained for all 129 cases and their 655 matched controls from two sources - hospital medical records and physician questionnaires (15). First, hospitalizattions with a primary discharge diagnosis of asthma during the two years preceding the index event or matching index date (not the hospitalization which might have occurred at the time of the life-threatening episode) were identilied from the computerized databases. Abstractors, blind to the study hypothesis and unaware of the case/control status of the subjects, visited hospital medical record departments and, using a standard form, obtained information from the patients' charts on precipitating factors, presenting respiratory symptoms and their duration, past history, signs of a life-threatening attack, lung function and atterial blood gases.

Second, the computerized out-paltient physician datafile was used to identify physician visits by study subjects. Eligible visits were those in which a general practitioner, pediatrician, internist, allergist or respirologist had seen the study subjects in the two years before the index date or event. Questionnaires were hand delivered by research personnel to these physicians and were subsequently picked up on completion. Clinical information similar to that gathered from hospital medical records was sought from the physicians. Ethical approval was obtained from the appropriate agencies of Saskatchewan Health.

Study subjects for management classification: The subjects were the 129 cases of fatal and near-latal asthma pre-
TABLE 2

Characteristics of study subjects

\begin{tabular}{|c|c|c|}
\hline & Case patients & Controls \\
\hline Number of subjects & 129 & 129 \\
\hline Male (\%) & 54 & 12 \\
\hline & \multicolumn{2}{|c|}{ Mean $\pm S D$} \\
\hline Age (years) at index event & $30 \pm 15$ & $28+14$ \\
\hline $\begin{array}{l}\text { Number of office visits* } \\
\text { to specialists } \\
\text { to nonspecialists }\end{array}$ & $\begin{array}{l}10 \pm 11 \\
35+30\end{array}$ & $\begin{array}{r}6 \pm 10 \\
29 \pm 25\end{array}$ \\
\hline Number of hospitalizations ${ }^{\dagger}$ & $2.1 \pm 3.4$ & $1.1 \pm 1.3$ \\
\hline
\end{tabular}

"Visits were those made during the two years before the index event or date. Specialists included pulmonary medicine, allergology, pediatrics and internal medicine; ${ }^{\dagger} / \mathrm{n}$ which there was a primary or secondary diagnosis of asthma

viously identified, as described above. From the controls who were matched to each case, the first control per catse was selected in whom similar clinical information (ie, hospital record information) was or was not available. This was undertaken to ensure that cases and controls were classified according to comparable information. A total of 258 subjects were therefore included in the analysis. Because controls were listed by sex with females appearing first, they were more likely to be selected as controls for the present analysis.

Methods for management classification: For each casc and matched control a dossier of information was assembled. For the fatal case patients this included a copy of the death certificate, as well as autopsy and coroner reports when available. If the death occurred in hospital, a copy of the hospital discharge summary associated with the event wals also obtained. For the near-fatal case patients, at copy of the hospital discharge summary associated with the near-fiatal episode was retrieved. In addition to the information surrounding 'the event', additional clinical information was obtained from the hospital medical records for each calse and matched control who were hospitalized for an asthma-relatted episode during the two years betore the index event, as describad above.

Detailed exposure information regarding medication dispensed each month for the 12 -month period before the index event or matching index date was also obtained for each case patient and matched control from the Prescription Drug Datal Base of Saskatchewan Health. One unit of an inhaled betaagonist was equivalent to the dispensing of one metred dose inhaler (MDI). For other medications a unit represented the dispensing of one prescription, usually a one-month supply. For the physician revicw, bela-agonists were identilied by class only. and not by individual generic names.

Each of the dossiers for the cases and their matched control was reviewed independently by two clinicians experienced in the treatment of asthma. On the basis of the information available the clinicians classified the management of each subject as either 'incompatiblc' or 'at kast partially compatible' with the current emphasis in pharmacotherapy. These classifications were then collated to determine the number of cases and controls classificd ats 


\section{TABLE 3}

\section{Frequency of management classified as incompatible with current treatment guidelines in 129 matched pairs following clinician review}

\begin{tabular}{lccc}
\hline Classification & $\begin{array}{c}\text { Cases (\%) } \\
(\mathbf{n}=129)\end{array}$ & $\begin{array}{c}\text { Controls (\%) } \\
(\mathbf{n}=129)\end{array}$ & P value* $^{*}$ \\
\hline $\begin{array}{l}\text { At least one clinician } \\
\text { Classified treatment as }\end{array}$ & $63(48.8)$ & $26(20.2)$ & $<0.001$ \\
$\begin{array}{l}\text { incompatible } \\
\begin{array}{l}\text { Both clinicians classified } \\
\text { treatment as } \\
\text { incompatible }\end{array}\end{array}$ & $15(11.6)$ & $10(7.8)$ & $>0.05$ \\
& & & \\
\end{tabular}

"McNemar $\chi^{2}$ statistic; ${ }^{\dagger}$ These subjects were included in the 63 cases and 26 controls classified as treatment incompatible by at least one clinician

\section{TABLE 4}

\section{Correspondence between classification by clinicians and asthma management score}

\begin{tabular}{crc}
\hline Classification by clinicians & Number $(n=258)$ & Mean score \\
\hline Classified as incompatible by & & \\
both clinicians & 25 & 4.9 \\
one of the two clinicians & 64 & 4.0 \\
neither of the clinicians & 169 & 2.6 \\
\hline
\end{tabular}

'incompatible' as judged by both reviewers, as well as the number classified as 'incompatible' as judged by at least one of the reviewers. No attempt was made to halve the lwo clinicians judge the aldequacy of phatmacotherapy in an equivalent way, and their assessments were carried out without knowledge of the other clinician's judgement. Only general instructions were given as to the factors to be considered. These were the use of high or increasing doses of bronchodilators, especially inhaled beta-agonists, the underuse of inflammatory drugs and the use of contraindicated drugs. especially in relation to clinical cvents such as hospitilizattions. It was felt that greater sensitivity to inaldequacies in pharmacotherapy might be obtained by keeping the clinical evaluations independent in this waly, though at the price of at less adequate demonstration of the validity of such a clinical assessment.

To validate the subjective assessments made by the two clinicians and to provide a more objective measure of the quality of pharmacotherapy, an asthma management score was developed based on current pharmacological treatment guidelines (Table 1). This was considered necessary since the clinicians could not be blinded to the case control status, ie. the occurrence of a life-threatening event, and such knowledge may have resulted in their being more critical of the management in this group. The potential range for the management score was 0 10 10, with 0 reflecting pharmacological trealment most compatible with current guidelines, and 10 indicating treatment considered least compatible. This management score wats applicel to each of the cases and controls by another member of the research team, who was blind to the case and control status of each subject, using the same information the clinicians had reviewed. The weight given to the different elements of the score are somewhat arbitrity. This is necessarily so, since it is difficult to equate the preseription of a contraindicaled medication, for example, a beta-blocker, which occurred in one case, with a given level of overuse of bela-agonists. However, the weights given for the different levels of use of beta-agonists and anti-inflammatory agents are compatible with the dose-response relationships observed in the cohort of 12.301 subjects with asthma. Analysis: The frequency of management incompatible with current pharmacotherapy, as classified by the two clinicians. was compared in the cases and controls using the McNemar $\chi^{2}$ statistic for matched pairs. The mean asthmat management score was calculated for ciases and controls, and the paired $t$ test was used to determine whether there was a significant difference in the mean scores. In detemining the association between exposure to fenoterol and albuterol and management classified as incompatible, an unmatched odds ratio and 95\% confidence interval were calculated. This was undertaken since the outcome of interest was now the management classification in cases and controls combined.

\section{RESULTS}

Characteristics of study subjects are presented in Table 2. While the case patients and the controls were similar with respect to atge, consequent to the way controls were selected al larger percentage of the ciases were males $(54 \%)$ than in the controls $(12 \%)$. When examined in the cohort of 12.30$)$ patients ats a whole, sex was not alssocialed with ontcome (life-threatening episode of asthma). Furthermore, in the study sample, there was no sex difference in the type or quantity of pharmacotherapy recived. The present authors are, therefore. confident that the sex difference between cases and controls did not bias the results presented here. The calse patients used the services of physicians and were hospitatized more frequently than the controls.

The frequencies of management classilied as incompatible with the current emphasis in pharmacotherapy, as determined by the two elinician reviewers, are presented in Table 3. A significantly higher proportion of cases (subjects who hat died of asthmil, or experienced a near-fatal asthmaltic episode) than controls from each matched pair were classified as receiving treatment incompatible with current guidelines by at least one of the two clinician reviewers $(\mathrm{P}<0.001)$. For the situation in which both the clinicians classified the subject as receiving treatment incompatibie with current guidelines, the difference betwen the cases and controls did nol achieve statistical significance ( $P>0.05$ ), at least in part due to the small number of subjects classified in this way. Note that the 63 cases and 26 controls classified as having incompatible treatment by at least one clinician included the 15 cases and 10 controls classified as such by both clinicians.

The results of the asthma management score that was applied to cach of the case and control subjects revealed a score ranging from 0 to 8 for cases, and 0 to 7 for controls. with 10 being the maximum score possible. The cases had at statistically significant higher mean score (3.5) than did the 
TABLE 5

\section{Association between clinical classification of overreliance on beta-agonist and being dispensed fenoterol or albuterol in the prior 12 months}

\begin{tabular}{|c|c|c|c|c|c|c|c|}
\hline \multirow{4}{*}{ Fenoterol } & \multicolumn{7}{|c|}{ Overreliance on beta-agonists ${ }^{\star}$} \\
\hline & \multicolumn{2}{|r|}{ Yes } & \multirow{2}{*}{$\begin{array}{l}\text { No } \\
47\end{array}$} & \multirow[b]{2}{*}{ Albuterol } & \multicolumn{2}{|r|}{ Yes } & \multirow{2}{*}{$\begin{array}{l}\text { No } \\
168\end{array}$} \\
\hline & Yes & 9 & & & Yes & 16 & \\
\hline & No & 16 & 186 & & No & 9 & 65 \\
\hline \multicolumn{4}{|c|}{$\begin{array}{c}\text { Odds ratio } 2.2 \\
95 \% \mathrm{Cl} 0.94-5.13\end{array}$} & \multicolumn{4}{|c|}{$\begin{array}{r}\text { Odds ratio } 0.69 \\
95 \% \mathrm{Cl} 0.29-1.62\end{array}$} \\
\hline
\end{tabular}

"As judged by both clinicians. Cl Confidence interval

controls. (2.8: $\mathrm{P}<0.0002 .95 \%$ confidence interval 0.3101 .1$)$. with a higher score rellective of pharmacological treatment less compatible with current phamaleotherapy. The correspondence between the classification of treatment by clinician revicw and that of the asthmat management seore is provided in Table 4. The average scores are consistent with the clinicians" classification - a higher mean score (reflective of pharmacological treatment less compatible with current guidelines) corresponding to subjects who were classified as incompatible with current guidefines by both clinician revicwers, or hy one alone compared with subjects whose treatment was classified as at least partially compatible with the current emphasis in pham acotherapy.

Table 5 examines the relationship between the likelihood of at subjecl's treatment being classified as incompatible with current pharmacotherapy by both clinicians and whether they had been dispensed lenoterol rather than albuterol in the prior 12 month. The small number of subjects precludes achieving statistical significance. The trend lowards a posilive association between being dispensed fenoterol and being classified as overreliant on bronchodilators as opposed to the possible negative association between albuterol and appropriateness of drug therapy suggests, however, that these two inhaled beta-agonists were used in patticnts in whom the yuality of therapy was different. It may also suggest, in accordance with the results of Sears (5), that prescribing fenoterol may worsen the severity of the disease, which in turn would leald to al greater need for, or reliance on, bronchodilators.

\section{DISCUSSION}

In response to increasing asthma morbidity and mortality in many parts of the world. vatrious organizations have brought together experts in the treatment of asthmil to develop guidelines for asthma mamagement in the hope of favourably influencing prognosis in this common disorder (!)-13). An important aspect of these guidelines is the greater emphasis placed on early use of anti-inflammatory therapy and less reliance on bronchodilator therapy. This current emphasis in pharmacotherapy is based on several long term studies recently demonstrating the efficacy of inhaled steroids in decreasing asthma morbidity (9.16-18), suggestive evidence that regular use of bronchodilators may actually matke asthma worse (5, (), 19-21) and the strong association between overuse of inhaled betitagonists and life-threatening asthmid (14). In an attempt to estimate the impact on asthma morbidity that might result from this change in emphasis in the pharmacotherapy of asthma, we evaluated the urug therapy received by asthmatic subjects who had experienced a life-threatening allikck and compatred it with subjects of the same age and asthma severity who had not experienced a life-threatening episode. Nearly half of the cases of lific threatening asthma were judged by at least one clinician experienced in the trealtment of asthma to have received treatment that did not at least partially meet currently recommended therapy, compared with $20 \%$ of study subjects who did not experience such a life-threatening event. The most common pattern observed was the increasing use of various bronchodilators over time without any dispensing of preventive or anti-inflimmatory therapy (22).

To render the evaluation of therapy more objective, we developed a management score that was then applied to the trealtment regimens by an observer not experienced in the treatment of asthma. The score was formulated to reflect the hypothesis that excessive therapy with inhaled beta-agonist bronchodilators without concomitant use of anti-inflammatory therapy is ill-advised. Again, according to this score, cases of life-threatening asthma demonstrated greater divergence from current recommendations thatn subjects who had not experienced such attacks. As one would expect, since both the score and the clinical assessment are based on current standards of therapy, the score is higher among subjects in whom clinicians thought the therapy did not meet these standards. This provides some validation of the clinical assessments.

We and others (23) have reported at stronger association between fenoterol, as opposed to albuterol, use and fatal asthma. Such a difference might be explained if subjects who were prescribed fenoterol were at a greater baseline risk of an adverse event. Inasmuch as not being dispensed therapy that reflects current recommendations is a marker of increased risk, subjects dispensed fenoterol appear to be at greater risk. Such channelling of therapy to different risk groups has been found for fenoterol in another population (24). Our evidence for such differential prescribing can only be considered ats preliminary given the low statistical power available for such an analysis. This study was based on the examination of computer and clinical records of inlomation collected in the past. This limits the amount of detail available on nompharmacological therapy as well as on environmental risk factors for life-threatening asthma. If such filctors were associated with the pharmacotherapy dispensed in a different way in puticnts with a life-threatening episode of asthma thin in those without such a history, these factors could partly explain the relationships described.

\section{CONCLUSIONS}

The results presented show that cases experiencing fatal or near-fatal asthma were more likely than controls to have received inadequitt therapy as judged by current treatment guidelines (specilically less anti-inflammatory and more 
beta-agonist treatment). From this evidence. we suggest that less reliance on bronchodilators and greater use of antiinflammalory therapy may have a positive impact on asthma morbidity.

ACKNOWLEDGEMENTS: This study was supported by a grant from Bochringer Ingelheim Canada Inc. The study is based, in part, on data provided by the Saskatchewan Department of Health. The interpretations and conclusions contained herein do not necessarily represent those of the Government of Saskatchewan or the Saskatchewan Department of Health.

\section{REFERENCES}

I. Mao Y, Semenciw R. Morrison H. MacWilliam L. Davies J. Wigle D. Increased rates of illness and death from asthma in Canada. Can Med Assoc J 1987;137:620-4.

2. Burney PGJ. Asthma mortality in England and Wales: evidence for a further increase, 1974-84. Lancet 1986;ii:323-6.

3. Evans R, Mullally D, Wilson R, et al. National trends in the morbidity and mortality of asthma in the US. Chest 1987;91:65S-74S.

4. Benatar SR. Fatal Asthma. N Engl J Med 1986;314:423-8.

5. Sears M, Taylor D, Print C, et al. Regular inhaled beta-agonist treatment in bronchial asthma. Lancet 1990;336:1391-6.

6. van Schayck C, Dompeling E, Cees L, et al. Bronchodilator treatment in moderate asthma or chronic bronchitis: continuous or on demand? A randomised controlled study. BMJ 1991;303:1426-31.

7. Barnes P. A new approach to the treatment of asthma. $\mathrm{N}$ Engl $\mathbf{J}$ Med 1989;321:1517-27.

8. Cockcroft D, Hargreave F. Outpatient management of bronchial asthma. Med Clin North Am 1990;74:797-809.

9. Ernst P, Spitzer WO, Suissa S, et al. Risk of fatal and near-fital asthma in relation to inhaled corticosteroid use. JAMA 1992;268:3462-4.

10. International Asthma Management Project and NHLBI Institute. International consensus report on diagnosis and treatment of asthma. Eur Respir J 1992;5:601-41.

11. National Asthma Education Program. Guidelines for the diagnosis and management of asthma. 1991. J Allergy Clin Immunol 1991:88:425-534.

12. Hargreave F, Dolovich J, Newhouse M. The assessment and treatment of asthma: a conference report. J Allergy Clin
Immunol 1990;85:1098-111.

13. Consensus Group. Asthmat: at followvup statement from an international pediatric asthma consensus group. Arch Dis Child 1992;67:240-8.

14. Spitzer WO, Suissa S, Ernst P, et al. The use of beta-agonists and the risk of death and near death from alsthma. N Engl J Med 1992;326;501-6.

15. Ernst P, Habbick B, Suissa S, et al. Is the association between inhaled beta-agonist use and life-threatening asthma because of confounding by severity? Am Rev Respir Dis 1993;148:75-9.

16. Juniper EF, Kline PA, Vanzieleghem MA, Ramsdale EH, O'Byrne PM, Hargreave FE. Effect of long-term treatment with an inhaled corticosteroid (budesonide) on airway hyperresponsiveness and clinical asthma in nonsteroiddependent asthmatics. Am Rev Respir Dis 1990;142:832-6.

17. Haahtela T, Jarvinen M. Kava T. et al. Comparison of a B?-agonist, terbutaline, with an inhaled corticosteroid. budesonide, in newly detected asthma. $\mathrm{N}$ Engl J Med 1991;325:388-92.

18. Van Essen-Zandvliet EE. Hughes MD, Waalkens HJ. Duiverman EJ, Pocock SJ, Kerrebijn KF. Effects of 22 months of treatment with inhaled corticosteroids and/or beta-2-agonists on lung function, airway responsiveness, and symptoms in children with asthma. Am Rev Respir Dis 1992:146:547-54.

19. Cheung D, Timmers MC, Zwinderman AH, Bel EH, Dijkman JH, Sterk PJ. Long-term effects of a long-acting

$\beta_{2}$-adrenoceptor agonist, salmeterol, on airway hyperresponsiveness in patients with mild asthma. N Engl I Med 1992;327:1198-203.

20). Taylor DR, Sears MR, Herbison Gl', et al. Regular inhaled $\beta$ agonist in asthma: effects on exacerbitions and lung function. Thorax 1993;48:134-8.

21. Cockcroft DW, McParland CP, Britto SA, Swystun VA, Rutherford BC. Regular inhaled salbutamol and airway responsiveness to allergen. Lancet 1993;342:833-7.

22. Suissa S, Blais L, Ernst P. Patterns of increasing $\beta$-agonist usc and the risk of fatal or near-fatal asthmiı. Eur Respir J. (In press)

23. Crane J, Pearce N, Flatt A, el il. Prescribed fenoterol and death from asthma in New Zealand, $1981-83$ : case control study. Lancet 1989;i:917-22.

24. Petri H, Urquhart J. Herings R, Bakter A. Chatrateristics of patients prescribed three different inhalationial beta-2-agonists: an example of the channeling phenomenon. Post-marketing Surveillance 1991:5:57-66. 


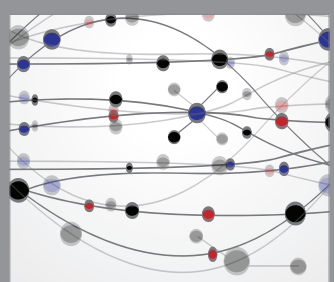

The Scientific World Journal
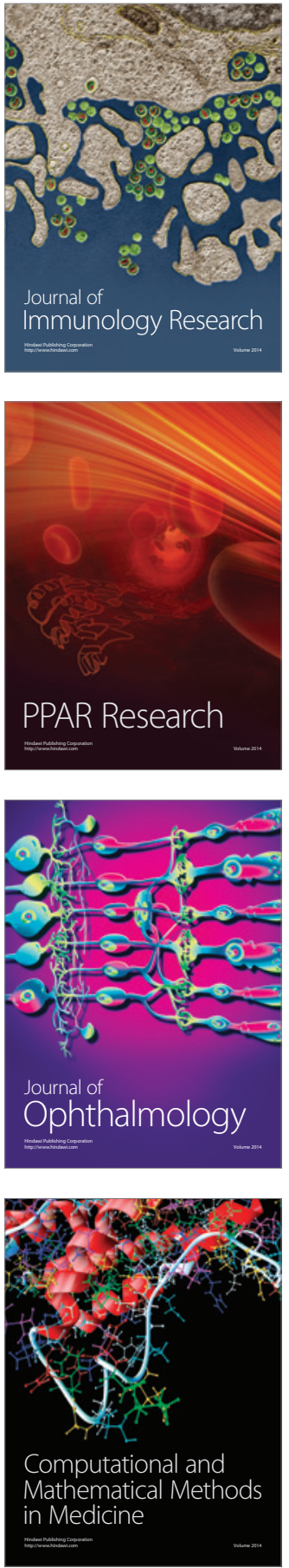

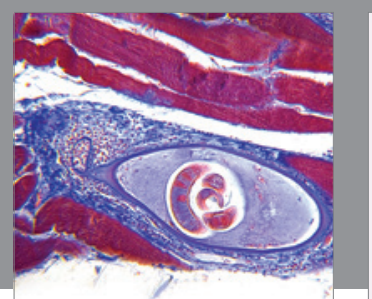

Gastroenterology Research and Practice

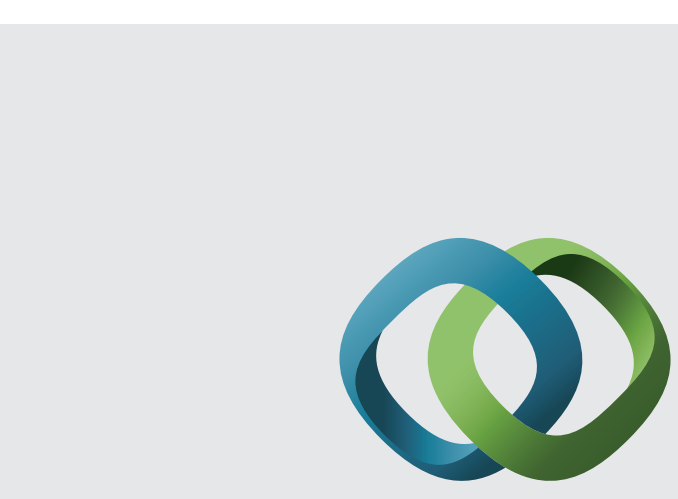

\section{Hindawi}

Submit your manuscripts at

http://www.hindawi.com
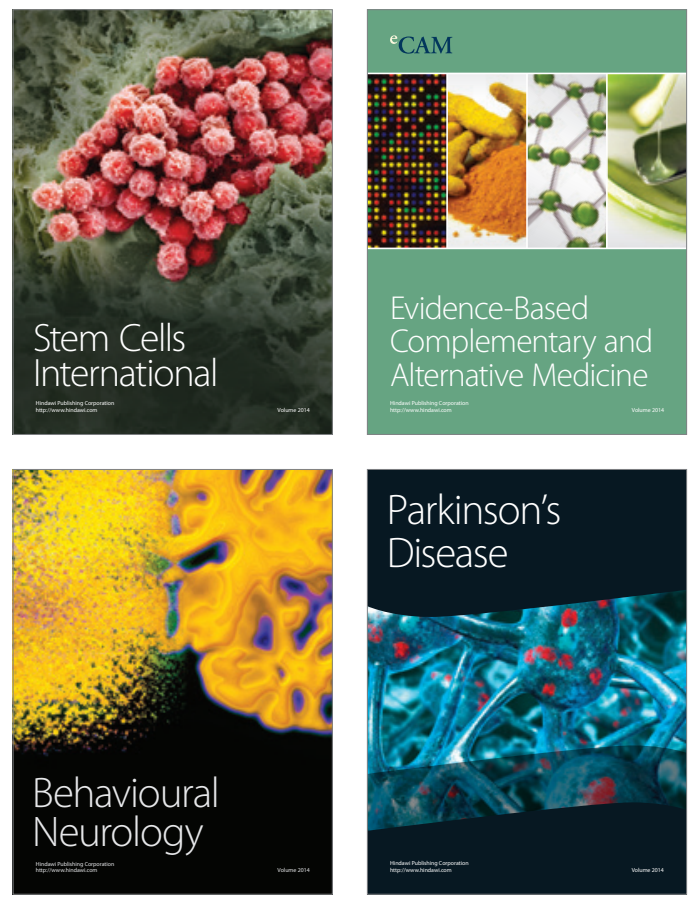
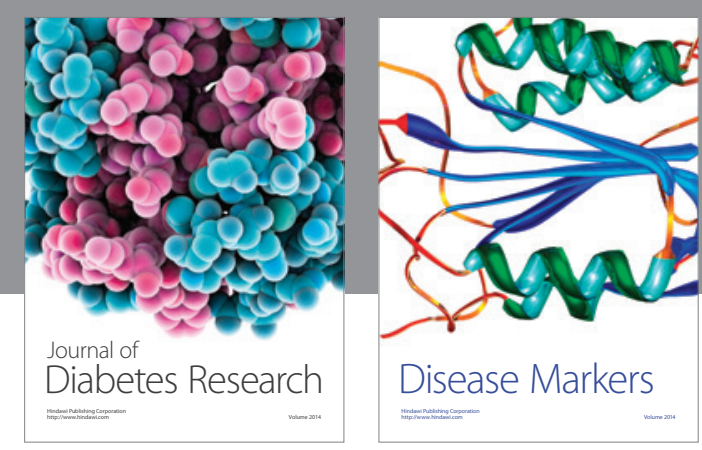

Disease Markers
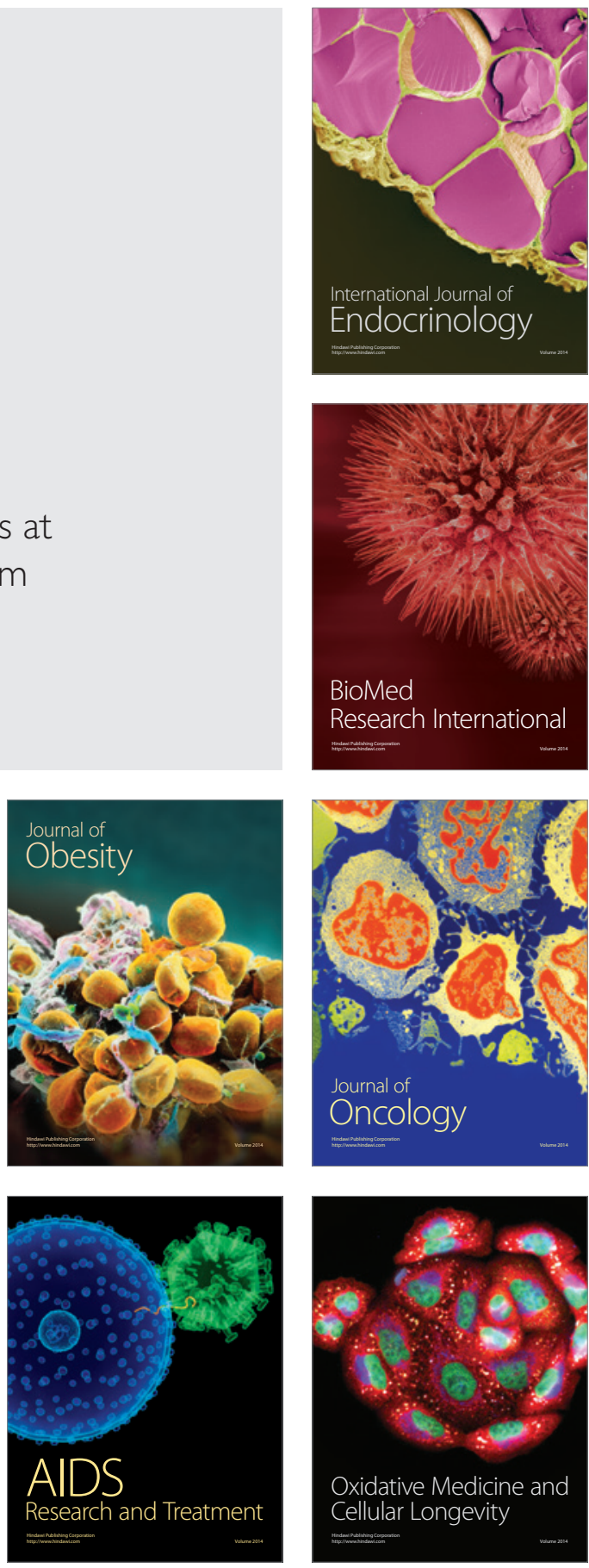